\title{
Liver Vitamin A Reserves of Very Low Birth Weight Neonates
}

\author{
JAYANT P. SHENAI, FRANK CHYTIL, AND MILDRED T. STAHLMAN \\ Departments of Pediatrics [J.P.S., M.T.S.] and Biochemistry [F.C.], Vanderbilt University Medical Center, \\ Nashville, Tennessee, 37232
}

\begin{abstract}
This study assessed the liver vitamin A concentrations at birth in a group of very low birth weight neonates $(n=25)(<1500 \mathrm{~g}$ birth weight, $<32$ wk gestation), dying within $24 \mathrm{~h}$ of birth, prior to possible changes in vitamin A status induced by postnatal intervention. Serum concentrations of vitamin $A$ and retinol-binding protein were also measured in $\mathbf{1 6}$ of these neonates. The mean $( \pm \mathrm{SD})$ liver vitamin $A$ concentration was $30.0 \pm$ $12.9 \mu \mathrm{g} / \mathrm{g}$ (range $2.0-49.0 \mu \mathrm{g} / \mathrm{g}$ ). The mean ( $\pm \mathrm{SD}$ ) serum vitamin A concentration was 13.0 $\pm 4.7 \mu \mathrm{g} / \mathrm{dl}$ (range 6.7$22.8 \mu \mathrm{g} / \mathrm{dl})$. The mean $( \pm \mathrm{SD})$ serum retinol-binding protein concentration was $2.2 \pm 0.8 \mathrm{mg} / \mathrm{dl}$ (range $1.5-4.8 \mathrm{mg}$ / dl). Liver vitamin A, serum vitamin A, and serum retinolbinding protein concentrations did not correlate significantly with gestational age or birth weight. Linear regression analysis did not show a significant correlation between liver vitamin A, and serum vitamin A or retinol-binding protein concentrations. This study provides reference values for vitamin A concentrations at birth in very low birth weight neonates, which may be helpful in future studies designed to evaluate postnatal changes in the vitamin $\mathbf{A}$ status of these high-risk neonates. (Pediatr Res 19: 892893, 1985)
\end{abstract}

Abbreviations

VLBW, very low birth weight

RBP, retinol-binding protein

Recent studies have shown that the plasma concentrations of vitamin A (retinol) and RBP at birth are lower in neonates of preterm gestation than in infants born at term $(1-3)$. Estimation of the vitamin A content of the liver is believed to be a more accurate indicator of the vitamin A status than the plasma concentrations of vitamin $A$ or $\operatorname{RBP}(4,5)$. This study was designed to assess the liver vitamin $A$ reserves at birth in a group of VLBW neonates dying within $24 \mathrm{~h}$ of birth, prior to possible changes in vitamin A status induced by postnatal nutritional manipulation or therapeutic intervention.

\section{MATERIALS AND METHODS}

Subjects. Liver tissue samples were obtained at autopsy from 25 neonates who died in the neonatal intensive care unit at Vanderbilt Medical Center. These infants (male $=14$, female $=$ 11) were $16-32 \mathrm{wk}$ gestational age (mean $\pm \mathrm{SD} ; 25.6 \pm 3.5 \mathrm{wk}$ )

Received November 14, 1984; accepted April 10, 1985.

Address for correspondence and reprint requests Jayant P. Shenai, M.D., Department of Pediatrics, Vanderbilt University Medical Center, Nashville, TN 37232.

Supported by Research Grants (SCOR HL 14214, HL 15341, and HD 09195) from the National Institutes of Health. and weighed $200-1410 \mathrm{~g}$ (mean $\pm \mathrm{SD} ; 814 \pm 345 \mathrm{~g}$ ) at birth. Eighteen infants were born within the hospital; the remainder were transferred from other hospitals within $4 \mathrm{~h}$ of birth. Eighteen infants were white; the remainder were black. None of the infants had congenital anomalies or evidence of intrauterine growth retardation. Death was secondary to complications of extreme prematurity and occurred within $24 \mathrm{~h}$ of birth in all cases. Massive intraventricular hemorrhage was the predominant cause of death. None of the infants received exogenous vitamin A during their brief postnatal life.

Autopsy procedures. Permission for a full autopsy was obtained from the parents in each case. The autopsy was performed within $12 \mathrm{~h}$ of death in all cases. Liver vitamin A concentrations are reported to remain unchanged in autopsy specimens for long periods, even after partial tissue autolysis (4). Liver tissue was obtained from the central portion of the right lobe. This portion was selected for analysis as it best reflects values for vitamin A concentration obtained from whole liver homogenates (6). The tissue was placed in a labeled, tightly capped plastic container protected from direct light and frozen at $-20^{\circ} \mathrm{C}$ until analysis. The analyses were performed within 2 wk of obtaining each sample. Storage for an extended period of time at below $0^{\circ} \mathrm{C}$ temperatures has been shown to cause no alteration in the tissue vitamin A content (7). A blood sample was collected from 16 of these infants at autopsy by direct cardiac puncture. The serum was separated from each sample by centrifugation and stored at $-20^{\circ} \mathrm{C}$ until analysis.

Chemical procedures. Serum vitamin A concentration was determined in duplicate by the fluorometric method described by Thompson et al. (8). The tissue samples were saponified in alcoholic $\mathrm{KOH}$ prior to extraction with hexane and assayed for vitamin A (8). Serum RBP concentration was determined in duplicate by quantitative radial immunodiffusion (M-partigen immunodiffusion plate plasma RBP (Calbiochem Behring Corp., La Jolla, CA).

Statistical analysis. Statistical analyses (mean, SD, linear regression, correlation coefficient, Student's $t$ test, and analysis of variance) were performed by using a Hewlett-Packard HP-55 programable calculator and the Statistical Package for the Social Sciences computer system.

\section{RESULTS}

The vitamin A and RBP concentrations from individual infants are shown in Figure 1. The mean $( \pm S D)$ liver vitamin $A$ concentration was $30.0 \pm 12.9 \mu \mathrm{g} / \mathrm{g}$ (range $2.0-49.0 \mu \mathrm{g} / \mathrm{g}$ ). The mean $( \pm \mathrm{SD})$ serum vitamin A concentration was $13.0 \pm 4.7 \mu \mathrm{g} /$ $\mathrm{dl}$ (range $6.7-22.8 \mu \mathrm{g} / \mathrm{dl})$. The mean $( \pm \mathrm{SD})$ serum RBP concentration was $2.2 \pm 0.8 \mathrm{mg} / \mathrm{dl}$ (range $1.5-4.8 \mathrm{mg} / \mathrm{dl}$ ). The individual concentrations of liver vitamin A, serum vitamin A, and serum RBP showed no significant differences with respect to sex or race, nor did they correlate significantly with gestational age or birth weight. Linear regression analysis did not show a significant 


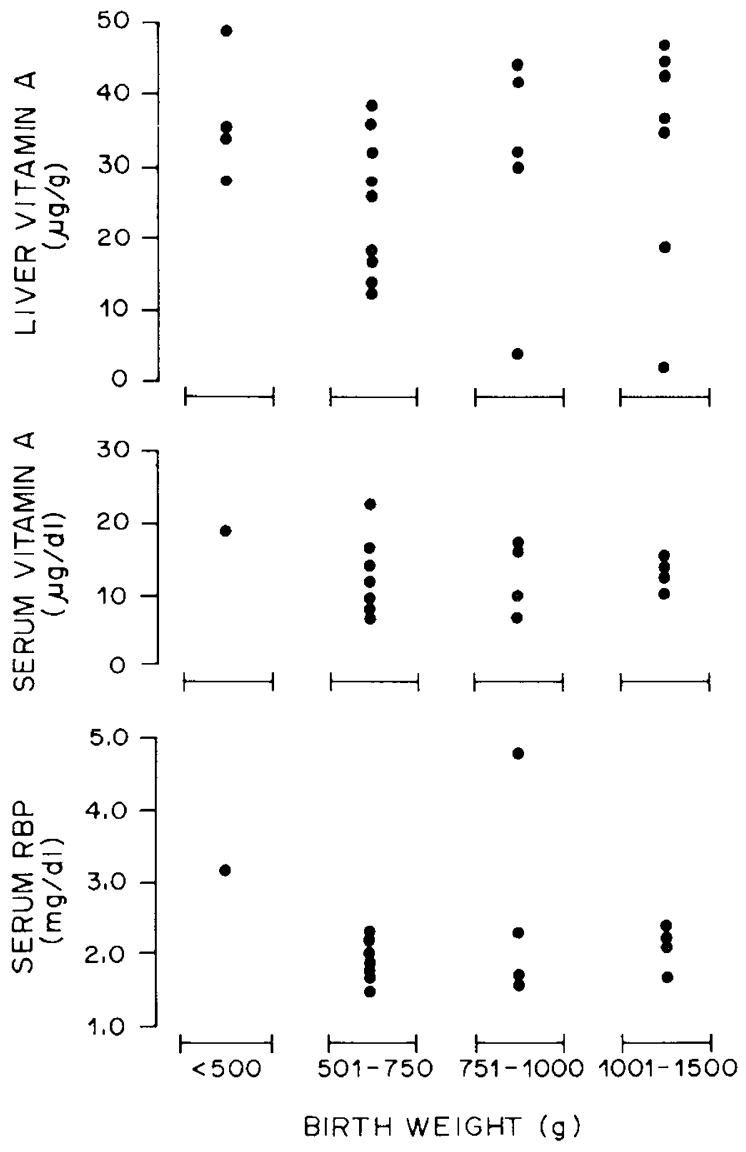

Fig. 1. Liver vitamin A, serum vitamin A, and serum RBP concentrations at birth in VLBW neonates.

correlation between liver vitamin $\mathrm{A}$, and serum vitamin $\mathrm{A}$ or RBP concentrations, nor did it show a significant correlation between serum vitamin A and RBP.

\section{DISCUSSION}

Inasmuch as $90 \%$ of the total body reserve of vitamin $\mathrm{A}$ is normally stored in the liver, measurement of the vitamin $\mathrm{A}$ concentration in a liver tissue sample taken at autopsy gives an accurate indication of the vitamin A status of an individual (4, $5,9)$. Based on surveys of victims of accidental death, an acceptable range of vitamin $A$ in the normal adult human liver is 100 $300 \mu \mathrm{g} / \mathrm{g}$ of tissue (9). The liver vitamin A concentrations in children vary markedly with age, being low during infancy relative to later childhood, adolescence, and young adulthood $(10,11)$. In children, a liver vitamin A concentration $<40 \mu \mathrm{g} / \mathrm{g}$ is generally considered to be indicative of low vitamin A reserve, and $<20 \mu \mathrm{g} / \mathrm{g}$ is considered as marginal or poor $(4,10,11)$. Similarly, a serum vitamin A concentration $<20 \mu \mathrm{g} / \mathrm{dl}$ and a serum RBP concentration $<3.0 \mathrm{mg} / \mathrm{dl}$ are considered to be suggestive of a suboptimal vitamin A status $(5,12,13)$.

Previous studies in stillborn infants and short-lived term neonates from the United States and Canada have reported a mean liver vitamin A concentration of approximately $40 \mu \mathrm{g} / \mathrm{g}$ of tissue $(6,14,15)$. Studies in preterm neonates from Brazil, Thailand, and India have reported mean liver vitamin A concentrations ranging from $16-33 \mu \mathrm{g} / \mathrm{g}$ of tissue (16-18). Studies from the United States in low birth weight $(<2500 \mathrm{~g})$ neonates dying within 6 days of postnatal life have reported a mean liver vitamin A concentration of $16 \mu \mathrm{g} / \mathrm{g}$ of tissue (11). Differences in ethnic background, wide ranges of gestational age, and varying time intervals between birth and death of these neonates account for the difficulties in using these data for comparative analysis. We therefore chose to examine a specific population of American preterm neonates who showed no evidence of congenital malformations or growth retardation, and who died within $24 \mathrm{~h}$ of birth, prior to possible changes in vitamin A status induced by postnatal intervention.

The serum vitamin A and RBP concentrations reported in this study are similar to the previously published cord blood values $(1-3)$. A high percentage of these neonates have serum vitamin $\mathrm{A}$ and RBP concentrations that may be considered as marginal or poor. The liver vitamin A concentrations reported in this study are similar to the previously published values in term neonates, but low relative to the published values in older infants and children. The serum levels of vitamin A do not reflect adequately the liver vitamin $A$ reserves in children and adults (19). The lack of correlation between serum vitamin A and liver: vitamin A concentrations in VLBW infants reported in this study is in agreement with that observation. Assessment of liver vitamin A stores is not feasible in clinical management of infants. Other more practical indicators of vitamin A status may need to be developed to facilitate sequential assessment and to optimize nutritional management of these high-risk neonates.

In summary, we have measured concentrations of liver vitamir A, serum vitamin A, and serum RBP in a group of short-lived VLBW neonates. Our study provides reference values at birth, which may be helpful in future studies designed to evaluate postnatal changes in the vitamin A status of these high-risk. neonates.

Acknowledgments. The authors gratefully acknowledge the expert technical assistance of Mark Hunt and Lucie Chytil.

\section{REFERENCES}

1. Brandt RB, Mueller DG, Schroeder JR, Guyer KE, Kirkpatrick BV, Hutcher NE, Ehrlich FE 1978 Serum vitamin A in premature and term neonates. J Pediatr 92:101-104

2. Shenai JP, Chytil F, Jhaveri A, Stahlman MT 1981 Plasma vitamin A anc retinol-binding protein in premature and term neonates. J Pediatr 99:302305

3. Bhatia J, Ziegler EE 1983 Retinol-binding protein and prealbumin in cord blood of term and preterm infants. Early Hum Dev 8:129-133

4. Olson JA 1978 Evaluation of vitamin A status in children. World Rev Nutr Diet 31:130-134

5. Pitt GAJ 1981 The assessment of vitamin A status. Proc Nutr Soc 40:173-178

6. Hoppner K, Phillips WEJ, Murray TK, Campbell JS 1968 Survey of liver vitamin A stores of Canadians. Can Med Assoc J 99:983-986

7. Parkinson CE, Gal I 1972 Factors affecting the laboratory management of human serum and liver vitamin A analyses. Clin Chim Acta 40:83-90

8. Thompson JN, Erdody P, Brien R, Murray TK 1971 Fluorometric determi. nation of vitamin $\mathrm{A}$ in human blood and liver. Biochem Med 5:67-89

9. Pearson WN 1967 Blood and urinary vitamin levels as potential indices of body stores. Am J Clin Nutr 20:514-525

10. Huque T 1982 A survey of human liver reserves of retinol in London. Br J Nutr 47:165-172

11. Olson JA, Gunning DB, Tilton RA 1984 Liver concentrations of vitamin A and carotenoids, as a function of age and other parameters, of American children who died of various causes. Am J Clin Nutr 39:903-910

12. O'Neal RM, Johnson OC, Schaefer AE 1970 Guidelines for classification and interpretation of group blood and urine data collected as part of the national nutrition survey. Pediatr Res 4:103-106

13. Vahlquist A, Sjolund K, Norden A, Peterson PA, Stigmar G, Johansson B 1978 Plasma vitamin A transport and visual dark adaptation in diseases of the intestine and liver. Scand J Clin Lab Invest 38:301-308

14. Lewis JM, Bodansky O, Shapiro LM 1943 Regulation of level of vitamin A in blood of newborn infants. Am J Dis Child 66:503-510

15. Mitchell GV, Young M, Seward CR 1973 Vitamin A and carotene levels of a selected population in metropolitan Washington, D.C. Am J Clin Nutr 26:992-997

16. Olson JA 1979 Liver vitamin A reserves of neonates, preschool children and adults dying of various causes in Salvador, Brazil. Arch Latinoam Nutr 29:521-545

17. Montreewasuwat N, Olson JA 1979 Serum and liver concentrations of vitamin $A$ in Thai fetuses as a function of gestational age. Am J Clin Nutr 32:601606

18. Iyengar L, Apte SV 1972 Nutrient stores in human foetal livers. Br J Nutr 27:313-317

19. Meyer KA, Popper H, Steigmann F, Walters WH, Zevin S 1942 Comparison of vitamin $A$ of liver biopsy specimens with plasma vitamin $A$ in man. Proc Soc Exp Biol Med 49:589-591 